Accepted refereed manuscript of: Allini A, Rakha S, McMillan D \& Caldarelli A (2018) Pecking order and market timing theory in emerging markets: The case of Egyptian firms, Research in International Business and Finance, 44, pp. 297 308. DOI: https://doi.org/10.1016/j.ribaf.2017.07.098

(C) 2017, Elsevier. Licensed under the Creative Commons AttributionNonCommercial-NoDerivatives 4.0 International

http://creativecommons.org/licenses/by-nc-nd/4.0/ 


\title{
Pecking order and market timing theory in emerging markets: The case of Egyptian firms
}

\author{
Alessandra Allini, Department of Economics, Management, Institutions, University of Naples \\ "Federico II", Via Cintia, Monte S. Angelo, 80126 Naples, Italy
}

Soliman Rakha, Business Administration Department, Damietta University, New Damietta, Egypt David G. McMillan, Accounting and Finance Division, Stirling Management School, University of Stirling, Stirling FK9 4LA, United Kingdom

Adele Caldarelli, Department of Economics, Management, Institutions, University of Naples "Federico II", Via Cintia, Monte S. Angelo, 80126 Naples, Italy

\begin{abstract}
Using a unique dataset of 1270 Egyptian listed firm-year observations over 20032014, we investigate whether the basic premises according to the pecking order or market timing theories provide an explanation for the capital structure mix of Egyptian firms. Current work has provided mixed evidence in regard to these capital structure theories in the Egyptian context. Our results show that the most profitable firms are less likely to resort to external financing. However, in case where financial deficits exist then equity issued appears to track the deficit rather than debt. Moreover, issuances appear to track deficit periods instead of market timing attempts. Results obtained support notion that the typical Egyptian firm follows revised pecking order theory, with the importance of the four conventional determinants, profitability, tangibility, size effect and growth opportunity in debt holdings.
\end{abstract}

Keywords: Capital structure; Pecking order theory; Market timing theory; Egypt

Accepted for publication in Research in International Business and Finance published by

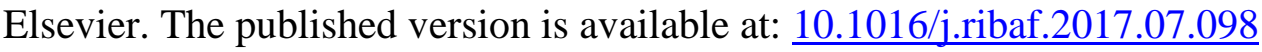




\section{Introduction}

The questions of how firms finance their operations and how they mix their capital structure have loomed large since the influential studies of Modigliani and Miller $(1958,1963)$ on capital structure irrelevancy. While it is widely recognised that the capital structure irrelevance theory is based on a set of unrealistic assumptions, it has been praised as the cornerstone of the modern finance over the past few decades (Ardalan, 2017). Subsequently, numerous studies have sought to explain the difference between observed capital structures across firms. This has led to a literature that is rich in variables designed to explain the influences upon capital structure decisions (see, Harris and Raviv, 1991).

The current study aims to provide a critical evaluation of two of the main contradictory capital structure theories. These are the pecking order theory (henceforth, POT) and market timing theory (henceforth, MTT). To do so, we use a panel data of firms from the Egyptian stock market (henceforth, EGX), which one of the oldest and, in terms of research, most untapped emerging markets.

Such an analysis is important for several reasons. To the best of our knowledge, this is the first study examining these two theories in the Egyptian context. As such, the findings will be of direct relevance to those agents involved in the Egyptian capital market, such as regulators, investors and firms. Perhaps more importantly, existing research is typically focused on developed markets and the US in particular. By considering an emerging market, this is, in effect, providing out-of-sample evidence for one or other of the above theories and thus stronger support for that theory.

The POT predicts that firms would prefer to rely on internal financing before issuing new securities. When firms are forced to obtain external financing, they would prefer secured debt, followed by risky debt before, finally, equity financing (Myers, 1984; Myers and Majluf, 1984; Shyam-Sunder and Myers, 1999). One theoretical challenge to POT comes from the MTT which argues that market timing has a significant and lasting effect on capital structure. Here, the firm's capital structure is a cumulative outcome of previous attempts to time the stock market through both issuances and repurchases or retirements (Baker and Wurgler, 2002; Hovakimian, 2006; Kayhan and Titman, 2007).

Several studies examining capital structure across different countries emphasize the role of country-specific factors, such as institutional frameworks and national culture. Such factors 
are likely to differ across developed and emerging markets (Rajan and Zingales, 1995; Booth et al., 2001; Acedo-Ramírez and Ruiz-Cabestre, 2014; Antonczyk and Salzmann, 2014; Belkhir et al., 2016). Moreover, the Egyptian market (similar to other emerging markets) is distinguished by two features which may prevent the generalisation of previous studies, on developed markets, to the Egyptian market. First, the Egyptian market is relatively less efficient compared to developed markets. Second, the information asymmetry and adverse selection problems are more severe within the Egyptian market than within developed markets (Ebaid, 2009; Eldomiaty and Ismail, 2009).

Furthermore, previous work also advocates the inability of any sole theory to provide a sufficient explain for corporate financing choices. Instead, it appears more realistic to consider a range of factors and theories in order to obtain a full understanding of firm's capital structure decisions (e.g., Shyam-Sunder and Myers, 1999; Myers, 2001; Frank and Goyal, 2003; Fama and French, 2005). The few studies that have been conducted within the Egyptian context are primarily focused on the effect of leverage on financial performance and the determinants of such leverage (see, Ismail and Eldomiaty, 2005; Ebaid, 2009; Eldomiaty and Ismail, 2009; Wahba, 2014; Belkhir et al., 2016). Therefore, this study fills gap within the Egyptian context and provides fertile ground for a comparison with results been drawn from developed economies.

To ensure the robustness of this study, we utilize a large and unique panel dataset that covers approximately half of the listed firms over the period from 2003 to 2014.

In preview of our results, we find mixed evidence for the two capital structure theories. Our findings suggest that the typical Egyptian firm prefers to rely on internal funds as its main financing source, which supports the predictions of the POT. However, in case of financial deficits, the magnitude of equity issued exceeds than of debt, which contradicts the predictions of the POT. Moreover, when observing the MTT assumptions, we do not find support for market timing attempts in Egyptian firms. This implies that the issuance activity of firms seems to be correlated with deficits instead of exploiting windows of opportunities in the equity market. Our results also emphasize the role of profitability, tangibility, size and growth opportunity within debt financing, which, in turn, reflects the emerging nature of the Egyptian market. In sum, we argue that Egyptian firms follow a revised pecking order theory, where equity is preferred to debt. 
The implications of these results will be useful to EGX regulators in structuring and developing capital markets, for managers in recognizing the need for a long-run vision for financing needs in order to reduce financing cost, and for investors in understanding how firms operate and providing reliable information for the benefit of investment decisions.

The rest of the paper is organized as follows. Section 2 provides a brief review of the prior literature; Section 3 describes the data and descriptive statistics; Section 4 discusses the models and variables definitions; Section 5 presents the findings and discussion and Section $\underline{6}$ concludes.

\section{Literature review}

\subsection{Pecking order theory}

Myers (1984) argues that firms do not have a targeted capital structure, instead firms would prefer to rely on internal financing rather than issuing new securities. Myers and Majluf (1984) advocate that due to the heterogeneity of information among market players (insiders and outsiders), firms prefer safe issuances and thus would rely on retained earnings as much as possible, only when investment opportunities exceed their cash flows would they utilise debt markets for external financing and in preference to more risky equity would act as a last resort to the extent that the firm may give up profitable opportunities rather than finance by risky securities.

In order to test POT empirically, Shyam-Sunder and Myers (1999) consider examining the empirical predictions of the theoretical model, in which firms rely on internal financing sources whenever possible. Only in the case of a financial deficit will the firm consider a hierarchy of external financing choices, in which secured debt is favoured, followed by risky debt and then equity. Their findings assert that POT is an excellent first-order descriptor of corporate financing behaviour for their firms sample.

Subsequently, further research has considered the empirical validity of the theory. Booth et al. (2001) reports findings across ten developing countries that are consistent with the POT, with the more profitable firm exhibiting a lower debt ratio. Sánchez-Vidal and Martin-Ugedo (2005) report that most Spanish firms adopt POT, whereby they tend to cover their financial deficits mainly with long term debts. Lemmon and Zender (2010) find that POT is a good descriptor of the observed financing behaviour for a wide cross section of firms, when 
controlling for debt capacity. Degryse et al. (2012) results support the POT behaviour in Dutch small and medium-sized enterprises (SMEs), noting that after internal funds, long-term debt is the next preferred source of capital. Tongkong (2012) provides further support for POT among Thai real estate companies, as high profit firms tend to have less debt, while high growth firms have higher debt ratios. Oino and Ukaegbu (2015) also show that firms in Nigeria follow POT to a certain extent. Chauhan (2016) finds a strong support for the pattern of financing as predicted by POT for firms in India.

Further to this, another branch of this research has identified what is referred to as a "modified" or "revised" POT. Chen (2004) notes that capital choice decision in Chinese firms seems to follow this modified POT, in which firms rely on retained profit, then equity, with long-term debt as a last option. Delcoure (2007) reveals that POT is insufficient to explain all financing patterns in central and eastern European countries. Instead, firms tend to follow the modified model of POT - namely retained earnings, equity, bank loans with debt's markets as a final choice. Wang and Lin (2010) revisited the POT and report that high market value firms are willing to issue equity while those with low market value issue debt. Strictly, they argued that the original POT could be reversed.

Other empirical studies, however, contradict the POT's predictions. For instance, Frank and Goyal (2003) reveal that although external financing is heavily used between U.S. firms. The debt financing however does not dominate equity financing in magnitude, and net equity issuance tracks financing deficit closer than debt. Fama and French $(2002,2005)$ argue that financing decisions running against POT. They report that equity issuance is both common and increasingly among U.S. firms from 1973 to 2002 and is related with financially constrained firms, also equity retiring is not rare. Flannery and Rangan (2006) also report findings inconsistent with the predictions of the POT. They argue that hierarchy behaviour only explains a small part of observed capital structure. Gaud et al. (2007) provide evidence that POT does not offer a suitable description of the capital structure policies in Europe. Karadeniz et al. (2009) show that POT is not able standalone for a complete explanation for capital structure of Turkish companies. Leary and Roberts (2010) report that POT exhibits poor performance in describing debt-equity issuance decisions. So that after allowing for variation in firms' debt capacities, they observe only fewer than $20 \%$ of firms follow the POT predictions. Chen et al. (2013) note that in the Taiwan stock market, net equity tracks the financial deficit much closer than debt issues do. They also show that the equity finance is 
greater than debt finance in most of the periods they consider. Komera and Lukose (2015) also reject the argument that firms follow POT in making their financing choices. They argue that debt does not dominate equity financing with Indian firms issuing a substantial amount of equity to cover their financial deficits

Finally, it has been noted that the original POT model exhibits some limitations. Namely, Chirinko and Singha (2000) argue that POT empirical model has a little power to distinguish between plausible patterns of external financing, which might lead to incorrect inference. Myers (2001) also argues that POT, as with other capital structure theories, works better under some conditions than others. Researcher may report results consistent with one theory even when actual financing decisions are determined by another. This implies that POT needs further support to distinguish it from other theories to be fully supported.

\subsection{Market timing theory}

While POT assumes semi-strong market efficiency, MTT does not rely on such an assumption. Therefore, a range of opportunities occurs as long as the cost of equity varies for either rational or irrational reasons. MTT has emerged due to the fact that a firm's financial settings changes over time, and that market inefficiencies can have important implications for corporate finance. Lucas and McDonald (1990) discuss the information-based model for the equity issuance decisions and finds that equity issuers on average have positive abnormal returns preceding the issuing. This implies that all firms whether overvalued or undervalued will try to time the equity market. However, both timing paths would differ due to the variance of adverse selection across firms. Ritter (1991) studies the variation across time- and industry-dependence of the long-run performance of initial public offerings, he show that the long-run underperformance of IPOs, year-to-year and across industries vary widely, meaning that issuing firms are trying to exploit "windows of opportunity".

Choe et al. (1993), based on analysis issue periods, reveals that firms sell seasoned equity when they face lower adverse selection costs. Thus, firms try to time the equity market in periods with more promising opportunities and with less uncertainty about assets in place. This finding suggests that the adverse selection varies across time. Loughran and Ritter (1995) point out that the firm will face a decline in performance in the long-run after stock issuance, confirming the hypothesis that firms exploit the temporary window of opportunity by issuing shares when significantly overpriced. Baker and Wurgler (2002) document that market timing behaviour has a large and permanent effects on firm's capital structure. They 
argue that the capital structure simply is a cumulative outcome of attempts to stock market timing. MTT posits that as information asymmetry and adverse selection change over time, the financing order would not be static, which contradicts POT.

Frank and Goyal (2004) note that a high market-to-book ratio is associated with subsequent debt reduction; however, they did not report any effect on equity issuing. Alti (2006) confirms the existence of market timing behaviour. He shows that hot-market IPOs firms issue substantially more equity, and have lower leverage ratios compared to cold-market firms. Hovakimian (2006) documents a significant negative impact of historical market-tobook ratios on capital structure. Although, he argues that the importance of historical average market-to-book ratios in leverage regressions is not due to past equity market timing but instead that historical ratios work as a proxies for growth opportunities. Bie and Haan (2007) find evidence of market timing by Dutch firms. They note that stock price run-ups lead to lower leverage and increase the probability of issuing equity rather than debt.

According to Kayhan and Titman (2007), firms' histories strongly influence their capital structures, since stock price changes and financial deficits affect capital structure changes. Gaud et al. (2007) provide evidence supporting the equity market timing approach where firms will take advantage of favourable market conditions. Huang and Ritter (2009) find that firms fund a larger proportion of their financing deficit with equity issues when the relative cost of equity is low. The historical values of equity cost would have long-lasting effects on firm's capital structure. Chen et al. (2013) show that market timing approach seems more favoured in the Taiwan stock market, since net equity tracks the financial deficit more closely than debt issues.

Accordingly, it is hard to argue that corporate financing decisions are made in accordance with a unique capital structure theory. Instead, it is more reasonable to assume that it is affected by different factors, internal (i.e. financial deficits) and external (i.e. market valuations) which requires further investigation. Our paper intends to add new insights to the studies by Ismail and Eldomiaty (2005) and Eldomiaty and Ismail (2009), testing for the first time whether POT and MTT are able, at once, to explain the capital structure decisions in the Egyptian market. 


\section{Data and summery statistics}

\subsection{Data and sample}

The Egyptian Exchange (EGX) - consisting Cairo and Alexandria - is one of the oldest stock market established in the Middle East. EGX was established in 1883 in Alexandria, followed by the Cairo Stock Exchange in 1903. EGX was very active in the 1940s and was ranked as the fifth in the world. The central planning and socialist policies adopted in the mid-1950s led to the market becoming dormant till 1990s. Following an economic reform program and privatization, the EGX has again grown. Over the period from 2002 till 2014, EGX has seen high growth rates in trading volumes (from LE 904mln to LE 57,231 mln), in trading values (from LE 34,176bln to LE 290,749bln) and in market capitalization (from LE 122bln to LE 500bln) (EGX Annual reports, 2002:2014). In addition, EGX annual performance based on Morgan Stanley Capital International Index (MSCI Index) ranged from 1.59\% to $29.36 \%$, compared with $-6.00 \%$ to $-1.82 \%$ for the emerging markets index, and with $-18.98 \%$ to $4.71 \%$ for all countries world index, in 2002 and 2014, respectively (www.msci.com). Therefore, we believe that the Egyptian stock market is a useful testing ground that merits further examination. The empirical analysis is conducted over the capital structure of 214 publicly-traded firms, published by EGX, covering the time-series for past twelve years from 2003 to 2014. Financial firms, utilities firms and firms with relatively missing data were excluded from our analysis. We obtain 106 firms with total 1270 firm-year observations.

Table 1 describes the structure of our panel dataset.

Table 1. Structure of Panel Dataset.

\begin{tabular}{l|l} 
A: Number of Observations on Each Firm & \\
\hline N. of Observations on Each Firm & N. of Firms \\
\hline 11 & 104 \\
\hline 12 & 106 \\
\hline Total & \\
\hline B: Number of Observations by Each Year & \\
\hline Year & \\
\hline 2003 & 105 \\
\hline
\end{tabular}




\section{B: Number of Observations by Each Year}
Year
N. of Observations

2004

C: Number of Firms by industrial sectors according to ICB Supersector

$\begin{array}{ll}\text { Industrial Sectors } & \text { N. of Firms }\end{array}$

Basic Resources

7

Chemicals

6

Construction \& Materials

19

Food \& Beverage

18

Health Care 8

Industrial Goods \& Services

8

Media

Oil \& Gas 2

Personal \& Household Goods 9

Real Estate 15

Retail 


\begin{tabular}{|c|c|}
\hline \multicolumn{2}{|c|}{ C: Number of Firms by industrial sectors according to ICB Supersector } \\
\hline Industrial Sectors & N. of Firms \\
\hline Technology & 1 \\
\hline Telecommunications & 3 \\
\hline Travel \& Leisure & 8 \\
\hline Total & 106 \\
\hline
\end{tabular}

It is worth noting that our sample (106) represents about 50 per cent of the total 214 listed firms in 2014. Our sample also includes those firms that contribute to the main indexes of the Egyptian Exchange, i.e., EGX30 and EGX100. Moreover, the market capitalization of our sample (LE 271bn) represents 54 per cent of the total market capitalization for all listed firms (LE 500bn) in Dec. 2014. Further, our sample size is larger than used in previous studies in the Egyptian context (see,Ebaid, 2009; Eldomiaty and Ismail, 2009; Wahba, 2014). Table 1C shows that the sample is slightly concentrated in the construction, food industries and real estate but no single industry dominates the sample.

\subsection{Descriptive statistics}

Table 2 presents the descriptive statistics of our variables. Egyptian firms appear to use debt financing unlike a typical firm in other emerging markets, the average debt ratio $17 \%$ is a very far from 51\% in developing countries (Booth et al., 2001), 46\% in Chinese firms (Chen, 2004), 56\% in Poland, $51 \%$ in Slovakia, $43 \%$ in the Czech Republic, and 34\% in Russia (Delcoure, 2007). Further, the Egyptian firm's debt ratio either 17\% for book-based debt, or $14 \%$ for market-based debt, seem very low compared with those in some developed countries as $39 \%$ and $35 \%$ in Canada, $48 \%$ and $41 \%$ in France, 38\% and 23\% in Germany, $47 \%$ and $46 \%$ in Italy, 53\% and 29\% in Japan, 28\% and 19\% in United Kingdom, and 37\% and 28\% in United States, respectively for book- and market-based debt ratios, (Rajan and Zingales, 1995), also very low than 49\% in Dutch SMEs (Degryse et al., 2012). These substantially low ratios of debts might reveal that equity capital financing is not rare nor might it be the last option for the Egyptian firms. The poor and inefficient bond markets, hard terms required and the strict control imposed by banks might force firms to prefer equity issues instead of bank loans.

Table 2. Summary Statistics. 


\begin{tabular}{|c|c|c|c|c|c|c|c|c|c|c|}
\hline & $N T D$ & $N N Q$ & $D E F$ & $B T D$ & $M T D$ & $L S A$ & $T A N$ & $P R F$ & MTB & EFWAMTB \\
\hline Obs. & 1264 & 1264 & 1264 & 1270 & 1270 & 1270 & 1270 & 1270 & 1270 & 1158 \\
\hline Mean & 0.0190 & 0.0698 & 0.1302 & 0.1702 & 0.1440 & 13.2068 & 0.3478 & 0.1243 & 1.4851 & 1.8028 \\
\hline Std Dev & 0.2725 & 0.4081 & 0.6848 & 0.2073 & 0.1735 & 1.6762 & 0.2378 & 0.1196 & 1.1612 & 4.9147 \\
\hline Min & -0.9008 & -0.4699 & -0.6163 & 0 & 0 & 8.2626 & 0.0001 & -0.7084 & 0.3503 & 0 \\
\hline Median & 0 & 0.0145 & 0.0510 & 0.0912 & 0.0762 & 13.1198 & 0.3476 & 0.1163 & 1.2011 & 0.3036 \\
\hline Max & 8.1631 & 12.0034 & 20.2768 & 0.7869 & 0.6949 & 18.3687 & 0.8775 & 0.5252 & 5.5690 & 16.6450 \\
\hline$N T D$ & 1.0000 & & & & & & & & & \\
\hline$N N Q$ & 0.6638 & 1.0000 & & & & & & & & \\
\hline$D E F$ & 0.8589 & 0.8725 & 1.0000 & & & & & & & \\
\hline$B T D$ & 0.1754 & -0.0123 & 0.0570 & 1.0000 & & & & & & \\
\hline$M T D$ & 0.1140 & -0.0327 & 0.0241 & 0.8143 & 1.0000 & & & & & \\
\hline$L S A$ & -0.0056 & -0.0475 & -0.0124 & 0.1565 & 0.1865 & 1.0000 & & & & \\
\hline TAN & 0.0215 & -0.0300 & -0.0223 & 0.2268 & 0.2880 & 0.2377 & 1.0000 & & & \\
\hline$P R F$ & -0.0808 & 0.0279 & -0.0247 & -0.3279 & -0.2514 & 0.1846 & 0.1033 & 1.0000 & & \\
\hline$M T B$ & 0.0630 & 0.0291 & 0.0298 & 0.2014 & -0.2092 & -0.0937 & -0.1375 & 0.0209 & 1.0000 & \\
\hline EFWAMTB & 0.0211 & 0.0036 & 0.0220 & -0.0217 & -0.0305 & -0.0344 & -0.0390 & 0.0619 & 0.0318 & 1.0000 \\
\hline
\end{tabular}

Notes: $N T D$ : net debt issued; $N N Q$ : net equity issued; $D E F$ : financial deficit, $B T D$ : book-based debt; $M T D$ : market-based debt; LSA: firm's size; TAN: tangibility; PRF: profitability; MTB: market-to-book ratio; EFWAMTB: "external financing weighted average" market-to-book ratio.

It is worth noting that the high mean and max values of net equity issued compared with net debt issued may refer to the preference of Egyptian firms to issue equity rather than debt in case of deficits. In turn, they may prefer to retire debt than equity in case of surpluses (negative deficits). The implication is that, in Egyptian firms, the equity issuance is usually higher than debt issuance; in contrary, the debt retirement seems higher than equity retirement, indeed even more so than the financial surplus. This appears to contradict the view that equity financing is scarce in Egyptian firms. In addition, the high values of MTB and EFWAMTB ratios implies that there are widows of opportunities in Egyptian equity market. 
In Table 3 we report the Kruskal-Wallis test in order to determine if there is a significant amount of variation across firms, industrial sectors and years. The Chi-sq statistics are significant for all variables across firms, except for EFWAMTB ratio. Also the Chi-sq statistics are significant for most variables across industrial sectors, except for financial deficit and EFWAMTB ratio which seem not significantly differ across sectors. Lastly, Chisq statistics are significant for most variables across years, except for net debt issued and tangibility which seems not to significantly differ over time.

Table 3. Kruskal-Wallis rank test for variables across firms, industrial sectors and years.

$\begin{array}{llll}\text { Variables } & \text { Chi-sq across firms } & \text { Chi-sq across sectors } & \text { Chi-sq across years } \\ \text { NTD } & 195.590^{* * * *} & 32.326^{* * *} & 17.087 \\ \text { NNQ } & 154.028^{* * * *} & 43.831^{* * * *} & 74.753^{* * *} \\ \text { DEF } & 163.536^{* * * *} & 12.585 & 45.115^{* * * *} \\ \text { BTD } & 822.852^{* * *} & 208.574^{* * *} & 50.035^{* * *} \\ \text { MTD } & 802.583^{* * *} & 190.709^{* * * *} & 73.613^{* * *} \\ \text { LSA } & 1158.523^{* * *} & 258.500^{* * * *} & 47.538^{* * * *} \\ \text { TAN } & 1076.258^{* * *} & 425.415^{* * *} & 2.209 \\ \text { PRF } & 841.984^{* * * *} & 233.364^{* * * *} & 42.073^{* * * *} \\ \text { MTB } & 567.392^{* * *} & 124.930^{* * * *} & 164.190^{* * *} \\ \text { EFWAMTB } & 94.260 & 14.681 & 192.906^{* * * *}\end{array}$

Notes: $N T D$ : net debt issued; $N N Q$ : net equity issued; $D E F$ : financial deficit, $B T D$ : book-based debt; $M T D$ : market-based debt; LSA: firm's size; TAN: tangibility; PRF: profitability; MTB: market-to-book ratio; EFWAMTB: "external financing weighted average" market-to-book ratio.

Indicates significance at $1 \%$ level.

\section{Models and variables}

\subsection{Pecking order model}


To test original POT, we adopt the methodology of Shyam-Sunder and Myers (1999) and empirically investigate the relation between debt issuance and the financial deficit. Assuming that firms will not issue new stocks after the initial public offering, the financing deficit should equal to net debt issues in normal operating conditions. The model has been widely used to verify POT (see, Chirinko and Singha, 2000; Frank and Goyal, 2003; Huang and Ritter, 2009; Lemmon and Zender, 2010; Komera and Lukose, 2015). Thus, the restricted model for original POT is given by Eq. (1):

\section{(1)NTDi,t= $\beta 0+\beta$ poDEFi,t+ei,t.}

Where, $N T D_{i, t}$ is the amount of debt issued (new debts), or retired, $\beta_{0}$ is the equation constant, $\beta_{p o}$ is the pecking order coefficient that under the original POT should equal one and $e_{i t}$ is the random error term. The firm's funds deficit has defined as the change in total assets minus change in retained earnings, as proposed by Fama and French (2005) and in later studies (e.g., Huang and Ritter, 2009; Komera and Lukose, 2015). Further, definition of the financial deficit been adopted by Watson and Wilson (2002) and tested by Sánchez-Vidal and MartinUgedo (2005) to examine how firms finance the deficit in assets growth. The variables $N T D_{i, t}$ and $D E F_{i, t}$ are normalized by the fiscal year-end total assets for firm $i$ at time $t-1$.

Interestingly, Chirinko and Singha (2000) argue that because of the presence of debt capacity constraints, the relation between net debt issued and financing deficit would be concave. To capture such a quadratic nature and identify the differences in financing choices between large and small deficits, Eq. (1) is augmented with the square of the financial deficit, DEFi,t2 (Lemmon and Zender, 2010; Komera and Lukose, 2015). Thus, our unrestricted model for the original POT becomes:

(2)NTDi, $t=\beta 0+\beta$ poDEFi, $t+\beta$ po,sqDEFi,t2+eit.

Should Egyptian firms follow the original POT but are constrained by concerns over debt capacity, then this should result in a significantly negative $\beta_{p o, s q}$ coefficient, an increase in the $\beta_{p o}$ coefficient, and an increase in the $R$-square (Chirinko and Singha, 2000; Lemmon and Zender, 2010; Komera and Lukose, 2015).

If the original POT holds then debt will dominate as the source of external financing. Alternatively, should the revised POT prevail then equity will be the preferred source of external financing. If this is the case then we would expect to have a relation between net equity issuance and the financing deficit. Therefore, to test the revised POT we follow Chen 
et al. (2013) and substitute the $N T D_{i, t}$ in Eq. (1) with $N N Q_{i, t .}$. Hence, the restricted model for revised POT is given by:

(3)NNQi,t= $\beta 0+\beta p o D E F i, t+e i, t$.

Where $N N Q_{i, t}$ is the amount of equity issued (new equity) or retired (if $D E F_{i, t}$ is negative), again normalized by the fiscal year-end total assets for firm $i$ at time $t-1$. as with the model for the original POT, we also introduce a squared term to capture any constraints on funding. Thus, the unrestricted model of revised POT is given by:

(4)NNQi,t $=\beta 0+\beta$ poDEFi,t+ $+\beta$ po,sqDEFi,t2 + ei,t.

\subsection{Market timing model}

To investigate MTT, we utilize the regression model of Baker and Wurgler (2002) and Hovakimian (2006) that includes the EFWAMTB ratio variable alongside the four common explanatory variables which explained by Harris and Raviv (1991) and then empirically tested by Rajan and Zingales (1995) into a simple cross-sectional model, firm size, tangibility, profitability, and market to book ratio. Thus, the model which we estimate as in Eq. (5):

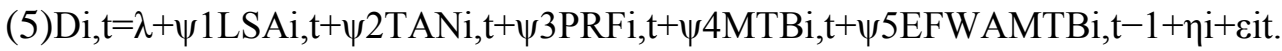

Where, $D$ is the firm's capital structure; $L S A$ is the firm's size; TAN is the tangibility; $P R F$ is the profitability; $M T B$ is the market-to-book ratio; $E F W A M B$ is the market timing variable. Following previous works, the variables are proxied as follow:

Capital structure $(D)$ is the ratio of total debt relative to the value of assets. We utilized two measures for capital structure based on computing capitalization, when equity is measured by book value, we term it as book-based total debt $(B T D)$, and when equity is measured at yearend market value, we term it as market-based total debt (MTD) (see, Rajan and Zingales, 1995; Frank and Goyal, 2009; Chakraborty, 2010; Chen et al., 2013).

Firm's size ( $L S A)$ is gauged by the natural logarithm of book value of assets. Tangibility $(T A N)$ is measured by net property, plant, and equipment relative to book value of assets. Profitability $(P R F)$ is measured by EBITDA relative to book value of assets, based on previous works (see, Chen, 2004; Delcoure, 2007; Frank and Goyal, 2009; Degryse et al., 2012; Antonczyk and Salzmann, 2014; Komera and Lukose, 2015, Bandyopadhyay and Barua, 2016; Belkhir et al., 2016). 
Market-to-Book ratio $(M T B)$ is measured by the market value of assets (book value of assets minus book value of equity plus market value of equity) divided by book value of assets. Market value of equity is stock price multiplied by shares outstanding. Following up previous works (see, Rajan and Zingales, 1995; Baker and Wurgler, 2002; Frank and Goyal, 2003, 2009; Hovakimian, 2006; Chen et al., 2013; Belkhir et al., 2016).

The market timing proxy (EFWAMB), which is the "external finance weighted-average" market-to-book ratio, summarizes the relevant historical variation in market valuations; following previous works (e.g., Baker and Wurgler, 2002; Hovakimian, 2006; Bie and Haan, 2007) we calculate EFWAMB as in Eq. (6).

(6)(MB)efwa, $t-1=\sum \mathrm{s}=0 \mathrm{t}-1 \mathrm{es}-\mathrm{ds} \sum \mathrm{r}=0 \mathrm{t}-1 \mathrm{er}+\mathrm{dr} \times(\mathrm{MB}) \mathrm{s}$,

Where, $e$ is net equity issued, measured as change in book equity minus change in retained earnings; $d$ is net debt issued, defined as the change in total debt. Then, for a firm observed at time $t$, the $E F W A M B$ is the weighted average of a time series of past market-to-book ratios, starting with the first observation in the sample and ending at $(t-1)$. The weight for each year is the ratio of external financing in that year to the total external financing raised by the firm. Hence, firms that issue securities when their market-to-book ratios are relatively high will tend to have high EFWAMB values, and in follow with Baker and Wurgler (2002) the negative weights are reset to zero.

\subsection{Financial deficit as an additional explanatory variable}

If Egyptian firms follow the predictions of the POT, then the inclusion of the financial deficit variable in a capital structure regression model should render the effects of four conventional explanatory variables insignificant; if not so then the predictions of the theory would be contradicted. (see, for example, Frank and Goyal, 2003; Chen et al., 2013; Komera and Lukose, 2015). Thus, we regressed the financial deficit term, together, with the four conventional determinants of firm's capital structure level. The model which we estimate is:

(7)Di,t= $=\lambda+\psi 1$ LSAi,t+ +2 TANi,t $+\psi 3$ PRFi,t $+\psi 4$ MTBi,t $+\varphi D E F i, t+\eta i+\varepsilon i, t$.

Where, variables definitions as outlined in subsections 4.1 and 4.3.

\section{Findings and discussion}

\subsection{Pecking order findings}


The above-stated models in Eqs. (1)-(4) were estimated by carrying out the most three common static linear panel data models, namely, Pooled-OLS, Fixed-effects and Randomeffects regression, respectively, as reported in Table 4. Diagnostic tests for models assumptions were performed. Heteroscedasticity and serial correlation are two problems that can affect the output of estimation models. Testing for heteroscedasticity was performed for the null hypothesis of homoscedastic by White-Koenker test using both levels and squares (White, 1980), as well modified Wald test for groupwise heteroscedasticity (Greene, 2003). Testing for serial correlation was performed by Wooldridge's serial correlation test (Wooldridge, 2002). Results in Table 4, under models (1) and (2) in Panel A and under models (7) and (8) in Panel B show only the presence of heteroscedasticity. Accordingly, both pooled-OLS and fixed-effects models (either restricted or unrestricted model) were performed with Driscoll-Kraay standard errors (Hoechle, 2007). Furthermore, Akaike Information Criterion (AIC) and Bayesian information Criterion (BIC) as the two most commonly used model selection criteria, were conducted for comparison between restricted and unrestricted models (Frank and Goyal, 2009; Wahba, 2014).

Table 4. Thee Estimators for Pecking Order Model.

\begin{tabular}{|c|c|c|c|c|c|c|c|}
\hline & \multicolumn{6}{|c|}{ Panel A: Original POT - Dependent Variable (NTD) } & \multirow{3}{*}{$\begin{array}{l}\text { Panel B: } \\
\text { Pooled-C } \\
\text { Model (7 }\end{array}$} \\
\hline & \multicolumn{2}{|l|}{ Pooled-OLS } & \multicolumn{2}{|l|}{ Fixed-Effects } & \multicolumn{2}{|l|}{ Random-Effects } & \\
\hline & Model (1) & Model (2) & Model (3) & Model (4) & Model (5) & Model (6) & \\
\hline DEF & $0.340^{* * *}(0.037)$ & $0.143^{* * *}(0.046)$ & $0.339 \stackrel{* * * *}{*}(0.034)$ & $0.136^{* * *}(0.041)$ & $0.340^{* * * *}(0.006)$ & $0.143^{* * *}(0.011)$ & $0.519 * * * *(1$ \\
\hline DEFi,t2 & & $0.013^{* * *}(0.002)$ & & $0.013^{* * * *}(0.002)$ & & $0.013^{* * *}(0.001)$ & \\
\hline $\mathrm{R} 2$ & 0.730 & 0.795 & 0.728 & 0.795 & 0.730 & 0.795 & 0.758 \\
\hline No. Obs. & 1264 & 1264 & 1264 & 1264 & 1264 & 1264 & 1264 \\
\hline F statistic & $85.60^{* * * *}$ & $10371.45^{\text {**** }}$ & $99.89^{* * * *}$ & $12994.59^{* * * *}$ & & & $118.37^{*}$ \\
\hline Wald $\chi^{2}$ & & & & & 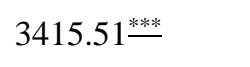 & $4876.27^{* * * *}$ & \\
\hline F-test & 0.87 & 1.01 & & & & & 0.75 \\
\hline B-P LM test & 0 & 0 & & & & & 0 \\
\hline Hausman Test & 0.79 & 4.14 & & & & & 0.59 \\
\hline
\end{tabular}


Pooled-OLS

Fixed-Effects

Model (3)

Model (4)

Random-Effects

Model (5)

Model (6)

Model (7)

White/Koenker

test

$443.586^{* * * *} \quad 586.321^{* * * *}$

Mod. Wald

test

$$
4.9 \mathrm{e}^{+05^{* * * *}} \quad 8.7 \mathrm{e}^{+06 * * *}
$$

Wooldrige test $\quad 0.285$

0.035

AIC

$-1352.215$

$-1694.539$

$-1448.517$

$-1805.28$

BIC

$-1341.931$

$-1679.112$

$-1438.233$

$-1789.854$

Notes: $N T D$ : the net debt issued, or retired; $N N Q$ : the net equity issued, or retired; $D E F$ : financial deficit; $\mathrm{DEFi}, \mathrm{t} 2 .:$ financial deficit squared. White/Koenker heteroscedasticity test was performed using both levels and squares of IVs. Pooled-OLS and Fixed-effects models were performed with Driscoll-Kraay standard errors, correcting heteroscedasticity problem. Values been expressed in parentheses are standard errors.

$* * *$

Indicates significance at $1 \%$ level.

With a view to the overall fit of the estimation model, the F-test was performed to decide between pooled-OLS and fixed-effects models (Greene, 2003), Results stated in Table 4 under models (1) and (2) in Panel A and under models (7) and (8) in Panel B show that pooled-OLS model is preferred. Hausman (1978) specification test also was conducted to decide between fixed-effects and random-effects models (Baltagi, 1995; Greene, 2003). Results stated in Table 4 under models (1) and (2) in Panel A and under models (7) and (8) in Panel B show that random-effects estimator is consistent. Furthermore, the Breusch and Pagan (1980) Lagrange Multiplier test (henceforth, B-P LM) was also conducted to decide between pooled-OLS and random-effects models (Green, 2003). Results stated under models (1) and (2) in Panel A and under models (7) and (8) in Panel B in Table 4 confirm that pooled-OLS is the most proper to test either original or revised pecking order model. As a final point for these results, both the AIC and BIC indicate a preference for the unrestricted model (i.e., the model that includes the squared financial deficit term).

Although the results stated in Table 4 under Pane A support a positive and significant coefficient of financial deficit on net debt issued. Yet, the estimated coefficient on financial deficit as 0.340 is still far below the theoretical coefficient suggested by Shyam-Sunder and 
Myers (1999) of being equal to one. Likewise, far below from observed coefficient in the U.S. market, that ranging between 0.75 and 0.85 (See, Shyam-Sunder and Myers, 1999). Sánchez-Vidal and Martin-Ugedo (2005) also held coefficients range from 0.65 to 0.94 for Spanish firms. Furthermore, the coefficient value decreases with inclusion the square of financial deficit, which in turn exerts a positive and significant coefficient, contradictory with POT predictions. And in terms of the model specification tests, the R-squared values range from $73 \%$ to $80 \%$. The results suggest that Egyptian firms do not follow the POT premise when making their financing choices and taken together with the above studies suggest a difference between developed and emerging markets. Alternatively, revised POT model is considered.

Interestingly, the results stated in Table 4 under Panel B exert a positive and significant coefficient of financial deficit on net equity issued. Moreover, it has a greater magnitude (0.519) than the corresponding value under the original POT. Furthermore, the coefficient value decreases (still also greater than obtained value under the original POT) with inclusion of the square of financial deficit, which in turn exerts a positive and significant coefficient. The R-squared values range from $76 \%$ to $78 \%$. This confirms that in Egyptian context, net equity issued is more related to financial deficit rather than net debt issued. This result holds across the six models considered (i.e., the restricted and unrestricted model for the three estimation approaches).

In Sum, In case of financial deficit, Egyptian firms seem more reliant on equity rather debt. Explanations for this result could include the lack of, or even absence of, the Egyptian bond market, insufficient corporate profits to meet debt obligations and the absence of strict laws to maintain equity holders' rights compared to the rigorous obligations toward debtholders. Accordingly, in Egyptian context, equity financing appears more attractive and potentially cheaper than debt. An alternative explanation might lie in the attempts by Egyptian firms to time the equity market. Thus, we now consider the MTT.

\subsection{Market timing findings}

The above-stated models in Eq. (5) was estimated also by carrying out the Pooled-OLS, Fixed-effects and Random-effects regression, for both BTD and MTD, as reported in Tables 5 and 6, respectively. Results in Tables 5 and 6, under models (1), (3) and (5) show the presence of both heteroscedasticity and serial correlation problems. Accordingly, pooledOLS model was performed with clustering standard errors, fixed-effects model was regressed 
by Prais-Winsten panel corrected standard errors that is robust to heteroscedasticity and the cross-sectional autocorrelation, as well, random-effects model was performed by Generalized Least Square (GLS) estimator with (AR1) (either BTD or MTD model). The F-test, as well AIC and BIC criteria show that fixed-effects is preferred over the pooled-OLS model. B-P LM test reveals that random-effects is preferred than pooled-OLS model. However, Hausman specification test shows that fixed-effects is preferred over random-effects model. The implication of these results is that the fixed-effects model is the appropriate model to test the market timing model (either BTD or MTD model). The $R$-squared values are $32 \%$ and $33 \%$ for BTD and MTD models, respectively.

Table 5. Three Estimators for Book-based Debt.

\begin{tabular}{|c|c|c|c|c|c|c|}
\hline \multirow{2}{*}{$\begin{array}{l}\text { Dependent } \\
\text { Variable: } B T D\end{array}$} & \multicolumn{2}{|l|}{ Pooled-OLS } & \multicolumn{2}{|c|}{ Fixed-Effects } & \multicolumn{2}{|c|}{ Random-Effects } \\
\hline & Model (1) & Model (2) & Model (3) & Model (4) & Model (5) & Model (6) \\
\hline \multirow{2}{*}{$L S A$} & $0.0237 * * *$ & $0.0233 * * *$ & $0.0283 * * *$ & $0.0293 * * *$ & $0.0195 * * *$ & $0.0156 * *$ \\
\hline & $(0.0082)$ & $(0.0081)$ & $(0.0048)$ & $(0.0045)$ & $(0.0064)$ & $(0.0065)$ \\
\hline \multirow{2}{*}{$T A N$} & 0.2253 & $0.2269 * * *$ & $0.1457 * * *$ & $0.1296 * * *$ & $0.0884 * * *$ & $0.0907 * * *$ \\
\hline & $* * *(0.0523)$ & $(0.0521)$ & $(0.0299)$ & $(0.0290)$ & $(0.0304)$ & $(0.0295)$ \\
\hline \multirow{2}{*}{$P R F$} & $-0.6691 * * *$ & $-0.6678 * * *$ & $-0.4892 * * *$ & $-0.5135^{* * *}$ & $-0.4424 * * *$ & $-0.4440 * * *$ \\
\hline & $(0.1229)$ & $(0.1169)$ & $(0.0492)$ & $(0.0488)$ & $(0.0408)$ & $(0.0394)$ \\
\hline \multirow{2}{*}{$M T B$} & $0.0450 *$ & $0.0419 *$ & $0.0337 * * *$ & $0.0340 * * *$ & $0.0316^{* * *}$ & $0.0326 * * *$ \\
\hline & $(0.0241)$ & $(0.0246)$ & $(0.0078)$ & $(0.0075)$ & $(0.0030)$ & $(0.0029)$ \\
\hline \multirow{2}{*}{ EFWAMTB } & $0.0001 *$ & & 0.0001 & & 0.0001 & \\
\hline & $(0.0001)$ & & $(0.0001)$ & & $(0.0001)$ & \\
\hline \multirow{2}{*}{$D E F$} & & $0.0132 *$ & & $0.0087 *$ & & $0.0102 * * *$ \\
\hline & & $(0.0074)$ & & $(0.0049)$ & & $(0.0031)$ \\
\hline $\mathrm{R} 2$ & 0.272 & 0.257 & 0.323 & 0.330 & 0.260 & 0.244 \\
\hline No. Obs. & 1158 & 1264 & 1158 & 1264 & 1158 & 1264 \\
\hline F statistic & $14.56 * * *$ & $15.19 * * *$ & & & & \\
\hline Wald $\chi^{2}$ & & & $200.12 * * *$ & $224.55 * * *$ & $235.37 * * *$ & $261.82 * * *$ \\
\hline F-test & $12.74 * * *$ & $12.88 * * *$ & & & & \\
\hline B-P LM test $\chi^{2}$ & $1436.47 * * *$ & $1564.47 * * *$ & & & & \\
\hline
\end{tabular}




\begin{tabular}{|c|c|c|c|c|c|c|}
\hline \multirow{2}{*}{$\begin{array}{l}\text { Dependent } \\
\text { Variable: } B T D\end{array}$} & \multicolumn{2}{|l|}{ Pooled-OLS } & \multicolumn{2}{|c|}{ Fixed-Effects } & \multicolumn{2}{|c|}{ Random-Effects } \\
\hline & Model (1) & Model (2) & Model (3) & Model (4) & Model (5) & Model (6) \\
\hline Hausman test $\chi 2$ & $18.61 * * *$ & $27.08 * * *$ & & & & \\
\hline $\begin{array}{l}\text { White/Koenker } \\
\text { test } \chi^{2}\end{array}$ & $383.497 * * *$ & $404.503 * * *$ & & & & \\
\hline $\begin{array}{l}\text { Mod. Wald } \\
\text { test } \chi 2\end{array}$ & $5.3 \mathrm{e}^{+05 * * *}$ & $4.1 \mathrm{e}^{+05 * * *}$ & & & & \\
\hline Wooldrige test & $48.607 * * *$ & $62.631 * * *$ & & & & \\
\hline AIC & -731.694 & -753.383 & -1685.095 & -1734.233 & & \\
\hline $\mathrm{BIC}$ & -701.367 & -722.531 & -1654.769 & -1703.381 & & \\
\hline
\end{tabular}

Notes: BTD: book-based debt; LSA: firm's size; TAN: tangibility; PRF: profitability; MTB: market-to-book ratio; EFWAMTB: external financing weighted average market-to-book ratio; DEF: financial deficit. White/ Koenker heteroscedasticity test was performed using both levels and squares of IVs. Pooled-OLS model was performed with clustering standard errors. Fixed-effects model was performed by Prais-Winsten panel corrected standard errors with (AR1). Random-effects model was performed by R-E GLS estimator with (AR1). Values been expressed in parentheses are robust standard errors. * and *** indicate significance at 10 and $1 \%$ levels, respectively.

Table 6. Three Estimators for Market-based Debt.

\section{Dependent}

Variable: Pooled-OLS

MTD

\begin{tabular}{|c|c|c|c|c|c|c|}
\hline & Model (1) & Model (2) & Model (3) & Model (4) & Model (5) & Model (6) \\
\hline \multirow{2}{*}{ LSA } & $0.0163^{* * *}$ & $0.0160 * * *$ & $0.0188 * * *$ & $0.0198 * * *$ & $0.0132 * *$ & $0.0136^{* *}$ \\
\hline & $(0.0058)$ & $(0.0060)$ & $(0.0039)$ & $(0.0037)$ & $(0.0053)$ & $(0.0056)$ \\
\hline \multirow{2}{*}{ TAN } & $0.1800 * * *$ & $0.1888^{* * *}$ & $0.1392 * * *$ & $0.1359 * * *$ & $0.0902 * * *$ & $0.0810 * * *$ \\
\hline & $(0.0403)$ & $(0.0419)$ & $(0.0257)$ & $(0.0243)$ & $(0.0252)$ & $(0.0251)$ \\
\hline \multirow{2}{*}{ PRF } & $-0.4117 * * *$ & $-0.4296 * * *$ & $-0.3249 * * *$ & $-0.3492 * * *$ & $-0.2818 * * *$ & $-0.2992 * * *$ \\
\hline & $(0.0606)$ & (0.0609) & $(0.0347)$ & $(0.0329)$ & $(0.0340)$ & $(0.0334)$ \\
\hline \multirow{2}{*}{ МТВ } & $-0.0207 * * *$ & $-0.0241 * * *$ & $-0.0200 * * *$ & $-0.0206^{* * *}$ & $-0.0182 * * *$ & $-0.0182 * * *$ \\
\hline & $(0.0062)$ & $(0.0071)$ & $(0.0028)$ & $(0.0029)$ & $(0.0025)$ & $(0.0025)$ \\
\hline
\end{tabular}




\begin{tabular}{|c|c|c|c|c|c|c|}
\hline \multicolumn{7}{|l|}{ Dependent } \\
\hline \multirow{2}{*}{$\begin{array}{l}\text { Variable: } \\
\text { MTD }\end{array}$} & \multicolumn{2}{|l|}{ Pooled-OLS } & \multicolumn{2}{|c|}{ Fixed-Effects } & \multicolumn{2}{|c|}{ Random-Effects } \\
\hline & Model (1) & Model (2) & Model (3) & Model (4) & Model (5) & Model (6) \\
\hline EFWAMTB & $0.0001 * *(0.0001)$ & & $\begin{array}{l}0.0001 \\
(0.0001)\end{array}$ & & $\begin{array}{l}0.0001 \\
(0.0001)\end{array}$ & \\
\hline $\mathrm{DEF}$ & & $\begin{array}{l}0.0059 \\
(0.0049)\end{array}$ & & $\begin{array}{l}0.0035 \\
(0.0032)\end{array}$ & & $\begin{array}{l}0.0004 \\
(0.0026)\end{array}$ \\
\hline $\mathrm{R} 2$ & 0.215 & 0.210 & 0.334 & 0.336 & 0.208 & 0.201 \\
\hline No. Obs. & 1158 & 1264 & 1158 & 1264 & 1158 & 1264 \\
\hline F statistic & $21.28 * * *$ & $18.91 * * *$ & & & & \\
\hline Wald $\chi^{2}$ & & & $222.44 * * *$ & $258.05 * * *$ & $154.22 * * *$ & $165.85^{* * *}$ \\
\hline F-test & $1.89 * * *$ & $9.47 * * *$ & & & & \\
\hline $\begin{array}{l}\text { B-P LM } \\
\text { test } \chi^{2}\end{array}$ & $945.78 * * *$ & $1035.27 * * *$ & & & & \\
\hline $\begin{array}{l}\text { Hausman } \\
\text { test } \chi^{2}\end{array}$ & $21.31 * * *$ & $34.70^{* * *}$ & & & & \\
\hline White / & & & & & & \\
\hline $\begin{array}{l}\text { Koenker } \\
\text { test } \chi^{2}\end{array}$ & $78.968 * * *$ & $89.856^{* * *}$ & & & & \\
\hline $\begin{array}{l}\text { Mod. Wald } \\
\text { test } \chi^{2}\end{array}$ & $1.3 \mathrm{e}^{+05 * * *}$ & $1.1 \mathrm{e}^{+05^{* * * *}}$ & & & & \\
\hline $\begin{array}{l}\text { Wooldrige } \\
\text { test }\end{array}$ & $201.116^{* * *}$ & $142.261 * * *$ & & & & \\
\hline AIC & -1172.976 & -1128.790 & -1922.476 & -1914.915 & & \\
\hline $\mathrm{BIC}$ & -1142.650 & -1097.938 & -1892.149 & -1884.063 & & \\
\hline
\end{tabular}

Notes: MTD: market-based debt; LSA: firm's size; TAN: tangibility; PRF: profitability; MTB: market-to-book ratio; EFWAMTB: external financing weighted average market-to-book ratio; DEF: financial deficit. White/ Koenker heteroscedasticity test was performed using both levels and squares of IVs. Pooled-OLS model was performed with clustering standard errors. Fixed-effects model was performed by Prais-Winsten panel corrected standard errors with (AR1). Random-effects model was performed by R-E GLS estimator with (AR1). Values been expressed in parentheses are robust standard errors. ** and *** indicate significance at 5 and $1 \%$ levels, respectively. 
Table 5 reports the results for book-based debt. Results reveal that the firm's size, tangibility and market-to-book ratio have a significant positive impact, while profitability has a significant negative coefficient, otherwise, EFWAMTB ratio have a non-significant positive impact on Egyptian firms' capital structure. Table 6 displays the results for market-based debt, confirming the significant positive coefficient of both size and tangibility, the significant negative coefficient of profitability, non-significant positive coefficient of EFWAMTB ratio, whilst, market-to-book ratio has a significant negative impact on marketbased debt.

Referring to the relationship between firm's size and capital structure, our results contradict the POT predictions, which assumes a negative sign, due to informational asymmetries becomes lower in larger firms, that then lead to more equity issuance. Our findings however consistent with previous evidence in various countries (e.g., Rajan and Zingales, 1995; Booth et al., 2001; Baker and Wurgler, 2002; Frank and Goyal, 2003, 2009; Chen, 2004; Bie and Haan, 2007; Delcoure, 2007; Degryse et al., 2012; Tongkong, 2012; Chen et al., 2013; Antonczyk and Salzmann, 2014; Komera and Lukose, 2015; Oino and Ukaegbu, 2015). One possible explanation is that size works as inverse proxy for the bankruptcy probability, financial distress costs and agency costs of debt, which implies better terms and lower cost of debt financing (Rajan and Zingales, 1995; Frank and Goyal, 2009). Moreover, firm size may also acts as a proxy for firm reputation. Lenders will be willing to lend larger firms than smaller ones especially in emerging markets, where the risk aversion is common. Additionally, larger Egyptian firms might have more access ability to capital market, and have a better negotiation position with banks, since they employ high-skilled staff who fabricate a stronger bargaining position towards lenders.

Regarding the relationship between tangibility and capital structure, also the results contradict POT that assumes a negative relationship, on the basis that firms with more tangible assets would face lower asymmetric information and thus more reliance on equity, and vice versa. Our results are consistent with previous evidence in other countries (e.g. Rajan and Zingales, 1995; Booth et al., 2001; Baker and Wurgler, 2002; Frank and Goyal, 2003, 2009; Chen, 2004; Delcoure, 2007; Karadeniz et al., 2009; Chakraborty, 2010; Degryse et al., 2012; Chen et al., 2013; Antonczyk and Salzmann, 2014; Komera and Lukose, 2015; Bandyopadhyay and Barua, 2016). The implication is that tangible assets are important in Egyptian context, since they can be used as collateral in order to help to overcome information problems and to 
attract debt financing. Additionally, it reduces the agency costs of debt, implying better terms and lower cost of debt financing.

Regarding profitability, our findings fully concur with the POT arguments about the inverse relation, as firms, generally, rely less on information-sensitive sources and prefer to use internally funds. This result is consistent with previous evidences (e.g., Rajan and Zingales, 1995; Booth et al., 2001; Baker and Wurgler, 2002; Frank and Goyal, 2003, 2009; Bie and Haan, 2007; Karadeniz et al., 2009; Chakraborty, 2010; Chen et al., 2013; Oino and Ukaegbu, 2015). Such a relation, particularly, seems more relevant for emerging markets, due to their typical features and firms' limited access ability to external financing market. Especially in a country like Egypt, with less efficient equity market, poor bond market and a semi bank-oriented financial system, the profitability role becomes vital, either in short-run to meet dividends and current needs, or in long-run as retained earnings to meet investments needs. The managers also may perceive retained earnings as the quickest and easiest financing source (Chen, 2004; Delcoure, 2007). At variance with relevant papers in Egyptian context, i.e. Ismail and Eldomiaty (2004) and Eldomiaty and Ismail (2009), our result documents the essential role of profitability as a debt financing determinant.

Market-to-book ratio results are mixed. That is, when employing book-based debt we report an significant positive relation. The same result is documented by other studies, e.g., Booth et al. (2001) in a set of emerging markets, Tongkong (2012) in Thai firms and Baker and Wurgler (2002) in U.S. firms. One explanation consistent with POT is that if market-to-book ratio works as a proxy for future opportunities, the highly-growth firms would face a greater asymmetric information problem and then in case of insufficient internal flows, they will accumulate debt to meet investments needs, hence, positive relation would notice. Contrary, by observing market-based debt, we report significant negative relation in consistent with previous evidence (e.g., Rajan and Zingales, 1995; Frank and Goyal, 2003; Chen et al., 2013; Komera and Lukose, 2015). Possible explanations that might drive the negative sign; first, firms with high market-to-book ratios have higher financial distress costs (Rajan and Zingales, 1995). Second, in accordance with MTT, firms might time equity market by issuing equity whenever the market-to-book ratio is high (Loughran and Ritter, 1995; Rajan and Zingales, 1995).

Last, with respect to the EFWAMTB ratio, we find that the historical market-to-book ratios don't have a long-lasting effect on Egyptian firms' capital structure, as it held insignificant 
positive coefficient. This implies that capital structure does not reflects cumulative attempts to timing stock market. Contradicting the market timing premises and in contrast with previous works (Baker and Wurgler, 2002; Hovakimian, 2006; Huang and Ritter, 2009; Bie and Haan, 2007). However, such result consistent with Leary and Roberts (2010) and Chauhan (2016) that the issuance activity of firms seems to be uncorrelated with market reactions.

\subsection{Further analysis for financial deficit as an additional explanatory variable}

Referring to our further analysis, we now examine the financial deficit as an additional explanatory variable and how its inclusion affects the above four noted variables. Table 5 under models (2), (4) and (6) reports the results for book-based debt. Results reveal that the financial deficit variable is significant. However, we can see that its inclusion does not affect the significance of the four conventional variables outlined. Moreover, there is no gain in terms of the R-squared value. Thus, it appears that this term offers little in explanatory power for the debt ratio. Table 6 under models (2), (4) and (6) as well displays the results for market-based debt, confirming that adding the deficit variable to the regression did not have much effect on the magnitudes and significance of the coefficients on the conventional variables. Thus, we can confirm reject of the pecking order theory in Egyptian firms.

This result is consistent with previous work, including Helwege and Liang (1996) who find that the financial deficit does not appear as a crucial determinant of firm's debt ratio. Equally, Frank and Goyal (2003) find that the financing deficit does not account for the effects of the conventional variables. Adding that the financing deficit only adds a small amount to the performance of the fitted model. Komera and Lukose (2015) also document that the introduction of the financial deficit in leverage specifications does not influenced the signs, magnitudes, and significance of the coefficients of conventional factors.

\section{Conclusions}

Employing panel data analysis, we investigate whether the basic premise of the pecking order and market timing theories can provide a complete explanation for the capital structure behaviour for Egyptian listed firms. We utilized a panel dataset of 1270 firm-year observations for about half listed firms from 2003 to 2014.

Consistent with the pecking order approach, our results confirm a negative and significant impact of profitability on capital structure. However, the estimated pecking order coefficient 
is far away from its theoretical value. Considering the revised pecking order approach, where equity is preferred to debt, stronger evidence is found, although, again, the estimated coefficient is below the theoretical value.

Our findings suggest that historical market-to-book ratios have not a significant effect on Egyptian firms' capital structure. As such, this provides no support for market timing attempts by Egyptian firms. Taking these results together, issuance activity in Egyptian context appears more closely to the need of funds instead of exploiting any windows of opportunity that may exist in equity markets. This may arise due to capital constraints faced by the firms. Hence, firms may not be able to issue adequate debt or equity when facing favourable market conditions. Another possible explanation is the absence of any long-term vision for future financial needs by Egyptian Managers. Thus, they will not be able to benefit from favourable market times.

Ultimately, we document that internally generated funds is the preferred option for Egyptian firms. Then, equity, where a financial deficit is present, and finally debt finance as a last resort. This may reflect the weakness of the debt market and restrictions imposed by banks as a major source of debt funds.

This study supports the literature that argues neither pecking order nor market timing theory are sufficient to provide a satisfactory explanation for capital structure behaviour.

Nonetheless, our results are consistent with several studies (e.g., Titman and Wessels, 1988; Rajan and Zingales, 1995; Frank and Goyal, 2009) that highlight the importance of four key characteristics - profitability, tangibility, firm size and the market-to-book ratio - as strong determinants of capital structure.

\section{Acknowledgment}

The authors are grateful for Egyptian ministry of higher education to fund current study.

\section{References}

Acedo-Ramirez \& M.A, Ruiz-Cabestre, F.J. (2014). Determinants of capital structure: United Kingdom versus continental European countries. Journal of International Financial Management \& Accounting, 25(3), 237-270.

Alti, A. (2006). How Persistent Is the Impact of Market Timing on Capital Structure?. The Journal of Finance, 61(4), 1681-1710. 
Antonczyk, R.C. \& Salzmann, A.J. (2014). Overconfidence and optimism: the effect of national culture on capital structure. Research in International Business \& Finance, $31,132-151$.

Ardalan, K. (2017). Capital structure theory: reconsidered, Research in International Business \& Finance, 39 (Part B), 696-710.

Baker, M. \& Wurgler, J. (2002). Market Timing and Capital Structure. The Journal of Finance, 57(1), 1-32.

Baltagi, B. (1995). Econometric Analysis of Panel Data. NY: John Wiley \& Sons.

Bandyopadhyay, A. \& Barua, M.N. (2016). Factors determining capital structure and corporate performance in India: studying the business cycle effects, The Quarterly Review of Economics and Finance, 61, 160-172.

M. Belkhir, M., Maghyereh, A. \& Awartani, B. (2016). Institutions and corporate capital structure in the MENA region, Emerging Markets Review, 26, 99-129.

Bie, T. D. \& Haan, L. D. (2007). Market Timing and Capital Structure: Evidence for Dutch firms. De Economist, 155(2), 183-206.

Booth, L., Aivazian, V., Demirguc-Kunt, A. \& Maksimovic, V. (2001). Capital Structure in Developing Countries. The Journal of Finance, 56(1), 87-130.

T.S. Breusch, T.S. \& Pagan, A.R. (1980). The Lagrange multiplier test and its applications to model specification in econometrics, The Review of Economic Studies, 47 (1), 239253.

Chakraborty, I. (2010). Capital structure in an emerging stock market: the case of India, Research in International Business \& Finance, 24, 295-314.

Chauhan, G.S. (2016). Reconciling theory and evidences for corporate financing in India, Journal of Emerging Market Finance, 15 (3), 295-309.

Chen, D-H., Chen, C-D., Chen, J. and Huang, Y-F. (2013). Panel Data Analyses of the Pecking Order Theory and the Market Timing Theory of Capital Structure in Taiwan. International Review of Economics and Finance 27, 1-13.

Chen, J. J. (2004). Determinants of Capital Structure of Chinese-Listed Companies. Journal of Business Research, 57(12), 1341-1351.

Chirinko, R. S. \& Singha, A. R. (2000). Testing static tradeoff against pecking order models of capital structure: a critical comment. Journal of Financial Economics, 58(3), 417425. 
Choe, H., Masulis, R.W. \& Nanda, V. (1993). Common stock offerings across the business Cycle: Theory and evidence. Journal of Empirical Finance, 1(1), 3-31.

Degryse, H., Goeij, P. \& Kappert, P. (2012). The impact of firm and industry characteristics on small firms' capital structure. Small Business Economics, 38(4), 431-447

Delcoure, N. (2007). The determinants of capital structure in transitional economies. International Review of Economics and Finance, 16(3), 400-415

Ebaid, I. E. (2009). The impact of capital structure choice on firm performance: empirical evidence from Egypt. Journal of Risk Finance, 10(5), 477-487.

Eldomiaty, T. I. \& Ismail, M. A. (2009). Modeling capital structure decisions in a transition market: empirical analysis of firms in Egypt. Review of Quantitative Finance and Accounting, 32(3), 211-233.

Fama, E. F. \& French. K. R. (2002). Testing Trade-Off and Pecking Order Predictions about Dividends and Debt. The Review of Financial Studies, 15(1), 1-33.

Fama, E. F. \& French. K. R. (2005). Financing decisions: who issues stock?. Journal of Financial Economics, 76, 549-582.

Flannery, M. J. \& Rangan, K. P. (2006). Partial adjustment toward target capital structures. Journal of Financial Economics, 79, 469-506.

Frank, M. Z. \& Goyal, V. K. (2003). Testing the pecking order theory of capital structure. Journal of Financial Economics, 67, 217-248.

Frank, M. Z. \& Goyal, V. K. (2004). The effect of market conditions on capital structure adjustment. Finance Research Letters, 1, 47-55.

Frank, M.Z. \& Goyal, V.K. (2009). Capital structure decisions: which factors are reliably important?, Financial Management, 38 (1), 1-37.

Gaud, P., Hoesli, M. \& Bender, A. (2007). Debt-equity choice in Europe. International Review of Financial Analysis, 16, 201-222.

Greene, W. H. (2003). Econometric Analysis, 5th ed. Upper Saddle River, NJ: Prentice-Hall.

Harris, M. \& Raviv, A. (1991). The theory of capital structure, Journal of Finance, 46 (1), 297-355.

Hausman, J.A. (1978). Specification tests in econometrics, Econometrica, 46 (6), 1251-1271. 
Helwege, J. \& Liang, N. (1996). Is There a Pecking Order? Evidence from a Panel of IPO Firms. Journal of Financial Economics, 40, 429-458.

Hoechle, D. (2007). Robust standard errors for panel regressions with cross-sectional dependence, The Stata Journal, 7 (3), 281-312/

Hovakimian, A. (2006). Are Observed Capital Structures Determined by Equity Market Timing?. The Journal of Financial and Quantitative Analysis, 41(1), 221-243.

Huang, R. \& Ritter, J. R. (2009). Testing Theories of Capital Structure and Estimating the Speed of Adjustment. Journal of Financial and Quantitative Analysis, 44(2), 237-271.

Ismail, M.A \& Eldomiaty, T.I. (2005). Bayesian identification of the predictors for capital structure in Egypt, Advances and Applications in Statistical Sciences, 5 (1), 1-20.

Karadeniz, E., Kandir, S. Y., Balcilar, M. \& Onal, Y. (2009). Determinants of capital structure: evidence from Turkish lodging companies. International Journal of Contemporary Hospitality Management, 21(5), 594-609.

Kayhan, A. \& Titman, S. (2007). Firms' histories and their capital structures. Journal of Financial Economics, 83(1), 1-32.

Komera, S. \& Lukose, J. (2015). Capital Structure Choice, Information Asymmetry, and Debt Capacity: Evidence from India. Journal of Economics and Finance, 39(4), 807-823.

Leary, M. T. \& Roberts, M. R. (2010). The pecking order, debt capacity, and information asymmetry. Journal of Financial Economics, 95, 332-355.

Lemmon, M. L. \& Zender, J. F. (2010). Debt Capacity and Tests of Capital Structure Theories. Journal of Financial and Quantitative Analysis, 45(5), 1161-1187.

Loughran, T. \& Ritter, J. R. (1995). The New Issues Puzzle. The Journal of Finance, 50(1), 23-51.

Lucas, D. J. \& McDonald, R. L. (1990). Equity Issues and Stock Price Dynamics. The Journal of Finance, 45(4), 1019-1043.

Modigliani, F, \& Miller, M.H. (1958). The cost of capital, corporation finance and the theory of investment, American Economic Review, 48 (3), 261-297.

Modigliani, F, \& Miller, M.H. (1963). Corporate income taxes and the cost of capital: a correction, American Economic Review, 53 (3), 433-443.

Myers, S. C. \& Majluf, N. S. (1984). Corporate Financing and Investment Decisions when Firms have Information that Investors do not have. Journal of Financial Economics, 13(2), 187-221. 
Myers, S. C. (1984). The Capital Structure Puzzle. The Journal of Finance, 39(3), 574-592.

Myers, S. C. (2001). Capital Structure. The Journal of Economic Perspectives, 15(2), 81-102.

Oino, L. \& Ukaegbu, B. (2015). The impact of profitability on capital structure and speed of adjustment: an empirical examination of selected firms in Nigerian Stock Exchange, Research in International Business and Finance, 35, 111-121

Rajan, R. G. \& Zingales, L. (1995). What Do We Know about Capital Structure? Some Evidence from International Data. The Journal of Finance, 50(5), 1421-1460.

Ritter, J. R. (1991). The Long-Run Performance of Initial Public Offerings. The Journal of Finance, 46(1), 3-27.

Sánchez-Vidal, J. \& Martin-Ugedo, J. F. (2005). Financing Preferences of Spanish Firms: Evidence on the Pecking Order Theory. Review of Quantitative Finance and Accounting, 25(4), 341-355.

Shyam-Sunder, L. \& Myers, S. C. (1999). Testing Static Trade off against Pecking Order Models of Capital Structure. Journal of Financial Economics, 51(2), 219-244.

Titman S. \& Wessels, R. (1988). The determinants of capital structure choice, Journal of Finance, 43 (1), 1-19.

Tongkong, S. (2012). Key factors influencing capital structure decision and its speed of adjustment of Thai listed real estate companies. Procedia - Social and Behavioral Sciences, 40, 716-720.

Wahba, H. (2014). Capital structure, managerial ownership and firm performance: evidence from Egypt. Journal of Management \& Governance, 18,1041-1061.

Wang, K-C. A. and Lin, C-H. A. (2010). Pecking-Order Theory Revisited: The Role of Agency Cost. The Manchester School, 78(5), 395-411.

Watson, R. \& Wilson, N. (2002). Small and Medium Size Enterprise Financing: A Note on Some of the Empirical Implications of a Pecking Order. Journal of Business Finance \& Accounting, 29(3) \& (4), 557-578.

White, H. (1980). A Heteroskedasticity-Consistent Covariance Matrix Estimator and a Direct Test for Heteroskedasticity. Econometrica, 48(4), 817-838.

Wooldridge, J. M. (2002). Econometric Analysis of Cross Section and Panel Data. London: MIT Press. 